gave to the Physiological Society. He became a member in 1920 and served on its committee during 1928-34. He was then elected treasurer of the Society, and fulfilled this onerous and responsible task for ten years, at a time when the rapid develop. ment of the Society demanded a wise and careful control of its finances. He was in this, as in so many of his activities, supremely competent and effective. His election to the Royal Society in 1944 held out the prospect of widening further the scope of the services he might give to science, great as they had already been.

In the memory of many, McSwiney will remain as an administrator and organiser; but good as he was at these tasks and great as was his flair for the strategy and tactics of the committee, his real place was as an inspiration and guide to his younger colleagues. He himself would never have claimed to be a great investigator, but those of us who had the privilege of working with him know that he had that peculiar quality of leadership which brought out the best in his collaborators in a happy spirit of comradeship.

G. L. Brown

\section{Prof. Gregori Aminoff}

GregorI Amrnofr, head of the Mineralogical Department of the Museum of Natural History (Riksmuseum), Stockholm, died on February 11, 1947. His death was caused by heart disease, which had during the last few years of his life greatly reduced his capacity for work.

Aminoff, who was born in 1883, belonged to an old Russian Boyar family, a member of which became a Swedish subject in the year 1612. He studied science in Stockholm and obtained his first academic degree in Uppsala in 1905. A strong artistic inclination caused him then to change his profession, and for several years he practised as an artist and studied art in France and Italy. About 1913 his old interest in science became predominant, with the result that he returned to studies in mineralogy. Aminoff's thesis for his doctorate, a crystallographic treatise on calcite and barytes from Långbanshyttan, appeared in 1918, and in the same year he was appointed lecturer in mineralogy and crystallography in the University of Stockholm.

In 1918 the Mineralogical Institute of the University of Stockholm acquired equipment for the X-ray investigations of crystals, and Aminoff was the first to use this apparatus, thus introducing $\mathrm{X}$-ray methods into Sweden. At first he studied several simple structures, and among them found the first representatives for the $C 6$ (brucite and pyrochroite) and $B 8$ (nickel arsenide) types. His very extensive studies over a period of several decades of the minerals from Långban also included much X-ray work.

In 1923 Aminoff was appointed a professor and head of the Mineralogical Department of the Museum of Natural History in Stockholm. After he had obtained adequate laboratory equipment in the Museum, he could take up his research work in the new surroundings. The Langban minerals occupied much of his time, but he also devoted himself to general problems, for example, the mechanism of evaporation and dissolution of crystals. His theoretical study of the contact zone between the two individuals of a twinned crystal is of great value. Aminoff also made use of electron diffraction, as, for example, in his study of the oxidation of zine sulphide crystals. In this case the known properties of the oxide and sulphide lattices explained the observed relative orientations of the two lattices, but could not explain the non-appearance of some orientations. In the studies last mentioned, as in much other work, Aminoff was assisted by his wife, Birgit BrooméAminoff.

In later years Aminoff was very interested in geochemical problems and made use of X-ray spectroscopy for his analytical work. He also spent much time trying to improve the technique of this method. Some of his latest papers (see, for example, Nature, April 20, 1946, p. 517) contained descriptions of his efforts to obtain large dispersion by using ground instead of natural crystal faces.

Aminoff was a born investigator who carried on his research for the sake of science. He was a very modest man of retiring disposition. This, together with the non-educational character of his institution, isolated him rather from the wider circles of Swedish science. But he never felt happier than when a friend dropped in at his laboratory with whom he could discuss his research problems. G. HÄGG

\section{Prof. Fred Vlès}

Fred VLès, zoologist and biophysicist, professor in the Faculty of Medicine at Strasbourg, died on July 2 , 1944, at the age of fifty-nine; he was one of a convoy of 2,500 political prisoners, taken by train from Compiègne to Dachau, of whom only 1,500 arrived alive. He had been arrested by the Gestapo at Clermont-Ferrand, where the University of Strasbourg had been evacuated. When warned that the German police were looking for him, he refused to hide for fear of possible reprisals on his colleagues.

Vlès had been a pupil of Yves Delage and was préparateur at the Roscoff Marine Biological Station during 1905-14. During the First World War he served in the Zouaves and was twice mentioned in dispatches. His only son, Claude, was killed in the Second World War, in the French aviation service. Vlès was a biologist with wide and original interests. He started as a zoologist, became more and more attracted to the physical chemistry of the cell, and eventually applied his knowledge to problems of human pathology. In 1921 he founded the Archives de Physique Biologique, and edited this journal until his death. He was one of the first to make use of cinematography in microscopy, in an investigation of the cleavage of the sea urchin egg in 1911 .

Many of Vlès' researches were in the field of spectroscopy, and through this I came to know him and appreciate his human and scientific qualities when working in his laboratory at Strasbourg on the spectroscopy of chlorocruorin. Vlès was very much le maître to his pupils, who had an immense admiration and affection for him. He made for himself a special place in French biology which will be difficult to fill.

H. MunRo Fox

WE regret to announce the following deaths :

Dr. I. Seymour A. Hadwen, formerly director of pathology and bacteriology at the Ontario Research Foundation, known for his work on animal pathology.

Prof. H. S. Jennings, emeritus professor of zoology in Johns Hopkins University.

Dr. S. A. Monckton Copeman, F.R.S., an authority on vaccination, on April 11, aged eighty-five. 